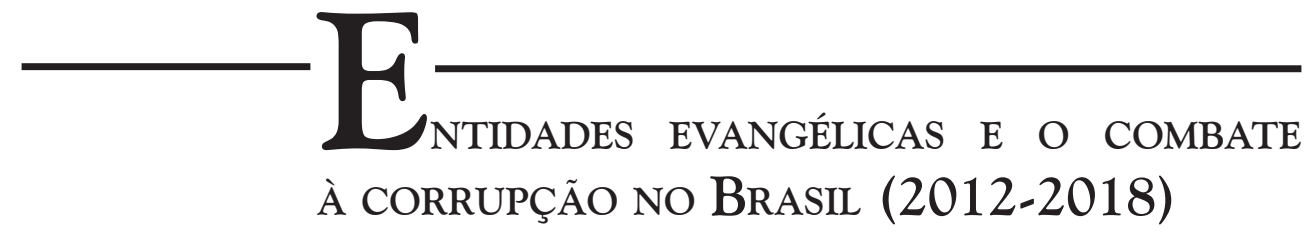

\author{
Marcos Otavio Bezerra \\ Universidade Federal Fluminense \\ Niterói - RJ - Brasil \\ Orcid: 0000-0002-9539-8175
}

Gabriela da Silva Moura Universidade Federal Fluminense Niterói - RJ - Brasil Orcid: 0000-0001-7233-9976

\title{
Entidades evangélicas e o combate à corrupção no Brasil (2012-2018)
}

O tema da corrupção adquiriu, sobretudo na última década, um lugar importante em eventos religiosos e posicionamentos públicos de lideranças religiosas e políticas de distintas denominações evangélicas. ${ }^{1}$ Em março de 2013, por exemplo, na Igreja Batista da Lagoinha, considerada a maior igreja histórica renovada de Belo

1 É consenso na literatura especializada a ideia de que o termo evangélico abarca, atualmente, um conjunto amplo e diversificado de denominações religiosas diferenciadas em termos de doutrina, número de fiéis, posicionamentos sobre temas públicos e poder econômico, midiático e político, entre outros aspectos. Ademais, as relações entre os segmentos evangélicos são atravessadas por afinidades e disputas. Segundo Novaes, a literatura "costuma diferenciar os pentecostais dos chamados protestantes históricos considerando a época de origem, a procedência geográfica e certas ênfases doutrinárias. Para os protestantes históricos, as referências são a Europa e a Reforma do século XVI. Para os pentecostais, de berço protestante, as referências são os Estados Unidos e o início do século XX. (...). De maneira geral, os pentecostais partilham a espera de uma segunda vinda de Cristo e acreditam ter acesso, no dia-a-dia, aos dons e carismas do espírito Santo" (Novaes 2002:74-75). Por conseguinte, cabe registrar que o uso da expressão campo evangélico ao longo do texto visa, especificamente, reconhecer a heterogeneidade e hierarquização existente entre os chamados evangélicos. 
Horizonte (MG), "palavras" ditas sobre a corrupção no Brasil durante um culto passaram a ser difundidas por veículos de comunicação evangélicos como "proféticas". ${ }^{2}$ Na ocasião, realizava-se o 14을 Congresso do Ministério de Louvor e Adoração Diante do Trono. ${ }^{3}$ A autora das "palavras" foi a pastora americana Cindy Jacobs, ${ }^{4}$ que anunciou: "E assim diz o Senhor: eu vou transformar o Brasil, mas vocês precisam transformá-lo através dos seus joelhos primeiro. E assim diz o Senhor: é meu desejo abater o principado da corrupção." O evento permite introduzir algumas das questões discutidas adiante. A menção à corrupção é realizada durante uma atividade não reconhecida propriamente como política, como as eleições, mas durante um evento religioso de rotina. A corrupção é interpretada nos termos de um discurso religioso. A presença da pastora americana no evento e a menção à corrupção chama atenção para articulações entre redes religiosas nacionais e internacionais em torno do tema. A corrupção, enfim, justifica o convite a uma forma de engajamento religioso e político com vistas a viabilizar um projeto de transformação social.

Três meses após a fala da pastora, as manifestações de junho de 2013 no Brasil foram interpretadas pelo site de notícias Gospel Prime, um veículo de comunicação que atende distintas denominações evangélicas com cerca de 3,5 milhões de visualizações mensais segundo o próprio site, ${ }^{5}$ como início da realização da referida profecia. Diante desses fatos que não nos parecem evidentes, este texto propõe investigar as condições sociais que promovem a difusão de narrativas sobre a corrupção e seu combate entre igrejas e entidades de denominações evangélicas.

A preocupação com o tema da corrupção no campo evangélico não é nova, mas sugerimos que há uma mudança no estatuto que ela adquiriu nos últimos anos. Inscrito no debate sobre a "ética na política", ele foi "amplamente explorado por segmentos religiosos nas eleições de 1998 e 2002" (Machado 2012:33). Em 2000, o discurso da "ética na política" e "purificação da política" justificou, no segundo turno das eleições municipais de Porto Alegre e Caxias do Sul, o decisivo apoio da Igreja Universal do Reino de Deus (Iurd) a candidatos do Partido dos Trabalhadores (PT) (Oro 2001). Na eleição nacional de 2010, o tema da corrupção se torna delicado em razão da participação de parlamentares evangélicos em fraudes em licitações para a

2 A profecia é uma forma de expressão por meio da linguagem na qual é possível se manifestar em relação ao futuro "não apenas como adivinhação", mas podendo ter um caráter de ação direta contra o diabo e males espirituais. Assim, um ato profético se encaixa dentre os diferentes dons atribuídos pelo Espírito Santo que estão presentes "no interior de vários pentecostalismos" (Sant'Ana 2017; Mafra 2001).

3 O Ministério de Louvor Diante do Trono, criado em 1998 na Igreja Batista da Lagoinha, foi idealizado por Ana Paula Valadão, filha do pastor Marcio Valadão. Ela reivindica a condição de autora de um novo gênero de música evangélica no meio cristão brasileiro, o "Louvor e Adoração", que se expandiu pelas capitais do Brasil, e chegou a reunir, em um único show, 2 milhões de pessoas (Rosas 2013).

4 Cindy Jacobs reside em Dallas, no Texas (EUA). Atua como conferencista internacional, é cofundadora da Generals International e autora de diversos livros sobre assuntos religiosos. Em 2019, em novo pronunciamento sobre o Brasil, declarou que o presidente Jair Bolsonaro estava transformando o Brasil em uma "nação de ovelhas".

5 A administração do site é da Gospel Prime Comunicação Digital LTDA. Entre os conteúdos oferecidos pelo portal estão: estudos bíblicos, notícias, vídeos, colunas de opinião e letras de músicas gospel. O portal tem redes sociais no Twitter e Facebook. 
aquisição de ambulâncias (denúncias investigadas pela CPI das Sanguessugas) e dá lugar à discussão sobre os Direitos Humanos (descriminalização do aborto, extensão de direitos aos LGBTQIA+ etc. (Machado 2013; Gonçalves 2017). Mas ele volta ao centro dos debates na eleição de 2014, quando o candidato à Presidência da República pastor Everaldo (PSC), membro da Igreja Assembleia de Deus, elege o combate à corrupção, ao lado da redução do Estado e da preservação da família, como uma das três principais bandeiras de sua campanha (Vital; Lopes; Lui 2017). Se, portanto, a preocupação não é recente, o que se observa, especialmente a partir de 2010, entre outros aspectos, é a incorporação do tema da corrupção na atuação ordinária de igrejas e entidades (encontros, cultos, orações), o surgimento de organizações e de movimentos de combate à corrupção a partir da articulação de diferentes denominações evangélicas e a publicação e circulação de textos informativos. A corrupção, portanto, parece ter adquirido uma importância no campo evangélico, pelo menos no período aqui delimitado, não observada anteriormente. ${ }^{6}$ Contribuir para explicar como isso foi possível e os efeitos que essa mobilização em torno do tema tem na definição de certa percepção sobre a corrupção são objetivos do texto.

A mobilização de segmentos evangélicos em torno da corrupção nesses últimos anos é indissociável de ao menos três fenômenos que precisam ser mencionados. O primeiro diz respeito à consagração que, graças à atuação de agências multilaterais, o combate à corrupção adquire na agenda pública internacional a partir dos anos 1990. A difusão de uma concepção de corrupção associada à opacidade, a adoção do princípio da transparência como solução, a produção de regulamentos anticorrupção e a promoção de acordos multilaterais de combate à corrupção são alguns dos produtos dessa mobilização internacional; que tem o Brasil como um dos países signatários (Glynn; Kobrin \& Naim 2002; Bratsis 2014). ${ }^{\text {? }}$

O segundo fenômeno concerne aos efeitos que as denúncias de corrupção publicizadas pela Operação Lava Jato, iniciada em 2014, tiveram nos debates públicos e nos arranjos políticos. A Operação reuniu o Ministério Público Federal, a Polícia Federal e a Justiça Federal, por meio da Vara Especializada em Crimes Financeiros de Curitiba (PR), na qual estava lotado o juiz Sérgio Moro. O principal foco da investigação foram os "esquemas de corrupção" identificados em contratos de aquisição de serviços celebrados pela empresa estatal Petrobras durante os governos do Partido dos Trabalhadores (PT) entre 2003 e 2016. Se o vínculo entre política e corrupção não era uma novidade na vida pública do país, o fato de ter sido descrito a partir de uma nar-

6 Esses elementos justificam o recorte temporal proposto. É nesse período que identificamos também uma maior incidência de discussões sobre o combate à corrupção nas fontes utilizadas. $\mathrm{O}$ material utilizado para a análise foi reunido, sobretudo, por meio de investigações na internet e inclui: matérias de sites das entidades religiosas, revistas e boletins de igrejas disponibilizados on-line, material escrito e audiovisual de curso on-line, vídeos de redes sociais, boletins de oração, fotografias, dentre outros

7 São produtos desses acordos a Lei da transparência (Lei complementar $n^{\circ}$ 131, de 27 de maio de 2009), a Lei de acesso a informações (Lei no 12.527 , de 18 de dezembro de 2011) e a Lei anticorrupção (Lei no 12.846 , de $1^{\circ}$ e agosto de 2013). 
rativa jurídica atribuiu-lhe novas formas de credibilidade e concorreu para a evolução da "crise política" que resultou no impeachment da presidenta Dilma Rousseff (PT), em agosto de 2016. A participação de coletivos religiosos nessa conjuntura, dentre eles os evangélicos, é analisada por Burity (2018). Atento às diferenças de posicionamento e comprometimento dos segmentos religiosos com os governos petistas, o processo de destituição da presidenta e a formação da nova coalizão governamental articulada pelo vice-presidente Michel Temer, o autor sustenta que o "bloco pentecostal hegemônico ("os evangélicos"/a "bancada evangélica") exerceu nesses episódios uma "força-chave" (Burity 2018:17). As evidências que reunimos aqui a partir da observação da circulação das narrativas de corrupção entre segmentos evangélicos e de suas articulações com órgãos da justiça corroboram a avaliação do autor.

O crescimento e a visibilidade da participação de denominações evangélicas na política é o terceiro fenômeno a se ter em conta. Se essa participação é anterior aos anos de 1990 (Novaes 2002), a literatura informa que é a partir da Constituição de 1988 que se observa um crescimento dos evangélicos, sobretudo de segmentos pentecostais, nos meios de comunicação, debates públicos e instituições políticas. Dentre as denominações pentecostais, a Iurd tem se destacado pelo número de parlamentares e vereadores eleitos desde os anos 1990 (Machado 2012, 2015; Novaes 2002, 2017; Oro 2001, 2003). Esse sucesso eleitoral é interpretado como resultado da adoção pela igreja do modelo corporativo de representantes, estratégia por meio da qual ela apresenta e apoia candidaturas oficiais, e que passou a ser adotado por outras denominações (Oro 2003). Não é demais lembrar que também no campo político os termos evangélicos e "bancada evangélica" não designam um grupo homogêneo nem um grupo com posições consensuais. Nesse sentido, cabe aqui reter o argumento de que “'os evangélicos' é um termo-valise, que expressa um bem-sucedido processo de hegemonização do campo protestante pelos pentecostais" (Burity 2018:16).

O interesse pela presença das denominações evangélicas na política institucional tem gerado contribuições importantes sobre temas como: a organização institucional de igrejas nas disputas eleitorais, a concepção de política vigente (visto como algo "sujo" e "desonesto") e as estratégias de apresentação de candidatos a partir de "modelo corporativo da candidatura oficial" (Oro 2001, 2003); o ponto de vista de lideranças pentecostais e a atuação de parlamentares evangélicos a respeito de temas culturais, identitários, políticos (aborto, questões de gênero, direitos humanos, corrupção e eleições) (Gonçalves 2017; Machado 2015; Prandi; Santos 2017; Vital; Lopes 2013); o sentido da participação na política como via de construção de um modelo alternativo de sociedade, concepções religiosas sobre representação política e formas de politização, formação de lideranças políticas e voto (Machado 2014, 2015; Novaes 2002, 2017); a influência (modesta) da religião na definição do posicionamento político de parlamentares evangélicos (Prandi; Santos 2017); o voto e as candidaturas evangélicas (Lacerda 2017; Oro 2001); a ocupação religiosa de espaços públicos (Luna 2018; Montero; Silva; Sales 2018; Sant'Ana 2014;) os aspectos 
conservadores e moralistas da atuação da bancada evangélica (Almeida 2017, 2019; Prandi; Santos 2017); entre outras.

É no âmbito de questões como as anteriormente indicadas que o tema da corrupção é mencionado. Abordado de forma apenas marginal ele não recebe a atenção que outros assuntos incluídos na agenda moral das denominações evangélicas recebem. Identificamos, no entanto, indicações preciosas sobre como doutrinas religiosas são mobilizadas na interpretação da corrupção. Referindo-se à Iurd e outras igrejas pentecostais, Oro $(2001 ; 2003)$ observa que, no período examinado, a corrupção é interpretada como a "antítese dos princípios cristãos", do "bem comum" e "inimigo do bem-estar dos cidadãos" (2003:57). Entendida como o produto da falha moral dos indivíduos, o ingresso de candidatos da igreja na política é defendido na medida em que são apresentados como uma "reserva moral da sociedade". Interpretada a partir de códigos religiosos, para a "IURD a batalha pela moralização enquadra-se no âmbito da batalha espiritual que abre espaço para um discurso que apela diretamente para "forças invisíveis" atuando na política" (Oro 2001:62). ${ }^{8}$

A caracterização por lideranças pentecostais da política como um meio repleto de vícios e corrupção e do cristão como moralmente virtuoso é destacada também por Machado e Burity (2014) e Machado (2015). Aqui chama atenção a referência que fazem os entrevistados a uma interpretação culturalista para explicar o que consideram os problemas da política. Assim, "enquanto o ethos pentecostal é associado à honestidade, ao trabalho duro e à seriedade, a cultura política do país é descrita como 'cheia de vícios' (...) capaz de desvirtuar 'das suas funções os homens tementes a Deus que se envolvem com a política”' (Machado; Burity 2014:619). Como evidencia o trecho de uma entrevista feita com um pastor da Igreja Assembleia de Deus, a concepção de si como moralmente íntegro vem acompanhada do senso de responsabilidade com o combate à corrupção no país: "Como é que eu, sendo luz, posso deixar que esse país fique por conta da corrupção e dos corruptos e não dou a minha participação como evangélico?" (Ibid). A condição de cristão justifica, portanto, o engajamento na política e na luta contra a corrupção. Torna-se, ademais, um dever moral.

Com a divulgação pela imprensa das informações reunidas pela Operação Lava Jato e a associação da corrupção especialmente aos governos e lideranças do Partido dos Trabalhadores (PT), a corrupção tornou-se um dos temas centrais das eleições de 2014 e das lutas políticas que culminaram no impeachment de Dilma Rousseff. Ao analisar os termos mencionados por deputados durante a votação do impeachment, em 17 de abril de 2016, Almeida (2017:72) registra que a corrupção, entendida como fonte maior dos problemas econômicos e éticos, foi o termo mais

8 A noção de batalha espiritual está presente entre diferentes segmentos religiosos evangélicos e no catolicismo. Sua cosmologia se apresenta na forma dualista em que uma guerra entre Deus e o Diabo se daria no cotidiano comum, sem haver, portanto, uma separação entre os males do plano divino e do plano terreno. Tem relação com a Teologia do Domínio na qual há uma ênfase na batalha contra demônios hereditários e territoriais e pode ser responsável por problemas pessoais, doenças, miséria e corrupção (Mariz 1999; Sant’Ana 2017). 
utilizado entre aqueles que votaram a favor do impeachment. Como propõe o autor, a condenação da corrupção se inscreve na defesa de uma maior moralidade pública e atuação de conteúdo conservador de evangélicos na política. A questão da corrupção volta a ser abordada por Almeida (2019) em artigo que examina a relação entre conservadorismo, evangélicos e a eleição para a Presidência da República de Jair Bolsonaro, em 2018. Com apoio de uma base parlamentar evangélica e identificado com a defesa de uma pauta de bons costumes, Jair Bolsonaro mobilizou um discurso anticorrupção e foi bem-sucedido ao associar a corrupção ao PT e à "velha política". $\mathrm{Na}$ esteira da Lava Jato e da imagem de excluído e crítico do sistema político, seu discurso ratificou a visão da política como fonte da corrupção e dos problemas do país.

As menções à religião e família durante a votação do impeachment de Dilma Rousseff são examinadas por Duarte (2017) a partir da questão sobre os valores morais presentes na Câmara dos Deputados. Se as referências religiosas causaram surpresa e foram objeto de atenção da imprensa, elas, no entanto, argumenta o autor, não refletem o grande número de parlamentares de distintas denominações religiosas vinculados às "bancadas" e "frentes" estruturadas em torno de pautas morais de caráter religioso. A importância e o significado dessas menções residem, no entanto, não na dimensão quantitativa, mas no lugar que ocupam no fragmentado mercado religioso. Nesse sentido, o autor lembra que "as posições morais sancionadas pelas instituições religiosas contemporâneas (pentecostais ou não) não emanam propriamente de sua disposição proselitista, mas se oferecem a parcelas da população que já se encontram predispostas a assumi-las e defendê-las" (Duarte 2017:160-161). $\mathrm{O}$ argumento, desse modo, nos parece mais um bom motivo para justificar o estudo sobre como narrativas da corrupção circulam no campo evangélico produzindo interpretações e posicionamentos a respeito do tema. ${ }^{9}$

Com base nas constatações anteriores e seguindo indicações de Muir e Gupta (2018) sobre áreas que merecem maior atenção nos estudos de corrupção, nos interessa, particularmente, o exame das condições sociais que propiciam o surgimento de iniciativas e a circulação de discursos sobre a corrupção no campo evangélico. Isso nos conduz, entre outros aspectos, a identificar as redes de contatos - religiosas e seculares, nacionais e internacionais - mobilizadas. Como os autores, concebemos a corrupção como uma categoria trans-histórica (como "desenvolvimento" ou "democracia") sujeita a apropriações e efeitos locais. Nesse sentido, consideramos a corrupção não uma categoria de análise, mas uma categoria avaliativa por meio da qual são produzidas críticas e julgamentos performativos em termos de legalidade ou ilegali-

9 O efeito das crenças e valores religiosos no combate à corrupção é uma das questões examinadas em estudos internacionais sobre a corrupção. Desses estudos retemos aqui somente a conclusão de que não existem evidências convincentes a respeito de uma relação direta entre interiorização de crenças religiosas em maior ou menor grau de corrupção. Assim, para uma melhor avaliação da relação entre esses dois fenômenos, os autores sugerem considerar, por exemplo, os múltiplos processos de socialização, o funcionamento das instituições e ideologias políticas e o modo como comunidades religiosas promovem interpretações e ações a respeito de questões tidas como de natureza pública. Ver a esse respeito Smith (2007), Marquette (2010) e Sommer, Bloom e Arikan (2012). 
dade, legitimidade ou ilegitimidade, sobre um conjunto variado de práticas (Muir \& Gupta 2018). Assim, ao seguirmos uma perspectiva de análise que tem sido explorada mais sistematicamente por estudos antropológicos sobre a corrupção, damos atenção aos significados associados às ideias de corrupção e seu combate e às suas implicações sociais e políticas (Haller \& Shore 2005; Muir \& Gupta 2018).

Para o desenvolvimento das questões anteriormente indicadas, examinamos campanhas e ações implementadas por igrejas e entidades evangélicas interessadas no combate à corrupção e, particularmente, a atuação de Igrejas Batistas na defesa e promoção da proposta elaborada pelo Ministério Público Federal (MPF) durante as investigações da Operação Lava Jato conhecida como as 10 Medidas Contra a Corrupção.

Olhar com cuidado para o modo como essas entidades evangélicas se apropriam da ideia de corrupção e lhes atribuem significados é uma forma de afastar a visão de que em diferentes contextos e grupos sociais a corrupção tem o mesmo sentido e os mesmos efeitos e, por conseguinte, de dar atenção aos diferentes usos sociais e às realidades produzidas com base na ideia da corrupção. Assim, ao demonstrarmos como a corrupção e o combate à corrupção são constituídos como objeto de preocupação no campo evangélico procuramos contribuir para a compreensão tanto dos caminhos pelos quais o tema ganha importância, se propaga, produz entendimentos e mobiliza interesses em um meio social específico, quanto das condições que favorecem a participação desse segmento religioso nas discussões de temas inscritos na agenda da política nacional

\section{Respostas de entidades evangélicas para a corrupção}

Além dos posicionamentos públicos de lideranças religiosas evangélicas condenando a corrupção, observamos a mobilização de redes evangélicas nacionais e internacionais, a criação de entidades, sites, produção de material escrito e audiovisual, oferta de cursos, realização de encontros, manifestações de rua, orações e coletas de assinaturas. Essas ações, precedem à Lava Jato, mas ganham força durante suas investigações. Elas mostram, por um lado, como a ideia do combate à corrupção ganha espaço entre coletivos evangélicos e, por outro, como contribuem para a difusão de narrativas sobre a corrupção. Menos do que as interpretações elaboradas sobre a corrupção a partir dos textos religiosos, interessa-nos, nesse momento, examinar como e por meio de que articulações e estratégias institucionais narrativas sobre a corrupção são postas em circulação e contribuem para a construção de percepções entre fiéis evangélicos não só sobre a corrupção e seu combate, mas também sobre política, democracia, justiça participação política e voto, entre outras questões.

A imagem reproduzida a seguir foi postada no site do coletivo Ame a Verdade: Evangélicos contra a Corrupção, sobre o qual falaremos adiante, em junho de 2017. Trata-se de uma montagem com o logotipo de organizações e campanhas de combate à corrupção que contam com o apoio de uma ampla rede internacional e nacional de 
entidades evangélicas predominantemente históricas. Produto de uma seleção, consideramos a foto, no entanto, como a objetivação do reconhecimento da importância dessas iniciativas e das entidades que a apoiam no campo evangélico. Nesse sentido, nos detemos a seguir nas organizações e campanhas inscritas na foto. Como já indicado, uma análise mais detalhada será realizada sobre a campanha de apoio ao projeto das 10 Medidas Contra a Corrupção. Além da grande publicidade, embates jurídicos e políticos suscitados pelo projeto, a observação das ações de divulgação e defesa das 10 Medidas permite observar o engajamento de Igrejas Batista e suas articulações com órgãos estatais de justiça.

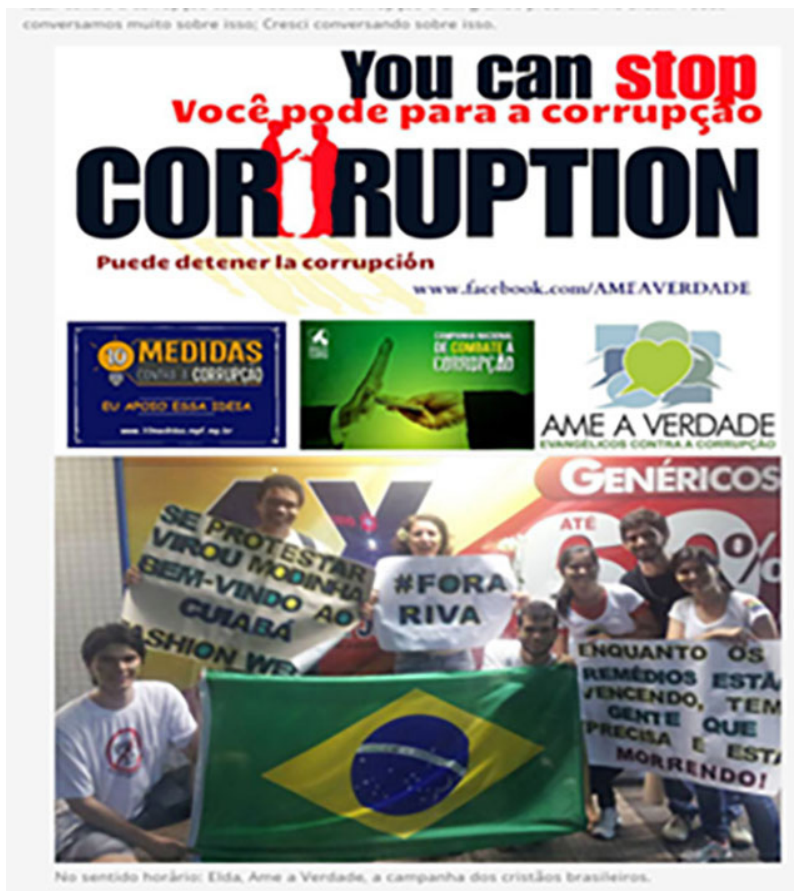

Imagem 1: De cima para baixo: logotipo da Exposed, em preto e vermelho, 10 Medidas contra a Corrupção, Campanha Nacional de Combate à Corrupção, Ame a Verdade e Elda Valin com outros cristãos. 15/06/2017. Fonte: http://ameaverdade.org/noticias/deixe-justica-subir-como-um-rio-justicacomo-um-fluxo-que-nunca-falha/. Acesso em: 30/03/2019.

Na parte superior da imagem, em preto e vermelho, vê-se o logotipo da Campanha Exposed. De âmbito internacional, a campanha foi lançada em Londres, em outubro de 2012, com o apoio da Sociedade Bíblica Britânica e Estrangeira, ${ }^{10}$ Desafio

10 A Sociedade Bíblica Britânica e Estrangeira foi criada na cidade de Londres, em 1804, sendo resultado de um movimento missionário protestante. Atua em 200 países, principalmente na China, África e Oriente Médio. Divulga a mensagem bíblica por meio de projetos de tradução e distribuição de bíblias, treinamento de liderança e projetos de alfabetização. Para mais informações, ver Escobar (2005). 
Miquéias Internacional, ${ }^{11}$ Corajosamente Éticos, ${ }^{12}$ Exército de Salvação ${ }^{13}$ e Aliança Evangélica Mundial (WEA). ${ }^{14} \mathrm{O}$ coordenador mundial da Campanha, Dion Forster, ministro da Igreja Metodista da África do Sul, manifestou-se a seu respeito nos seguintes termos: "Estou convencido de que estamos respondendo ao chamado de Deus para que a Igreja tome uma posição sobre a questão da corrupção em todo o mundo." E ao conceber a corrupção como um pecado contra os mais pobres ressalta a importância da Campanha: "[...] A corrupção é um pecado. É um pecado perpetrado contra os membros mais vulneráveis da sociedade. É uma afronta a Deus. É essa verdade que torna a Campanha Exposed tão importante e tão urgente" ${ }^{15}$ (tradução nossa). Os objetivos iniciais da Campanha eram três: coletar assinaturas para serem levadas à reunião do G20 na Austrália, em 2014; organizar uma vigília global contra a corrupção e fazer a divulgação de material informativo para cristãos envolvidos em negócios empresariais. É importante registrar que a associação entre corrupção e pobreza tem um lugar importante não só em discursos religiosos, mas também em discursos de agências multilaterais sobre os "países em desenvolvimento". Essa afinidade facilita, certamente, a circulação de visões sobre o tema e formas de cooperação entre igrejas e essas agências.

No Brasil, a Campanha Exposed foi lançada em junho de 2013 durante um culto na Igreja Congregacional Zona Sul, na cidade de Campina Grande (PB). A coordenação da Campanha ficou a cargo da Associação Nacional de Juristas Evangélicos (Anajure), entidade que reúne juristas e advogados evangélicos, criada em 2012, que atua no apoio a juristas, entidades e questões públicas de interesses dos segmentos evangélicos. ${ }^{16}$ Inspirado no livro de Isaías 54:1 ("A minha justiça será luz para as nações"), o slogan da

11 O Desafio Miquéias Internacional é uma organização internacional de cristãos criada em 1999. A entidade promove campanhas para redução da pobreza e para que os "Objetivos de Desenvolvimento do Milênio, medidas e metas criadas pela Organização das Nações Unidas (ONU) sejam alcançados". No Brasil, é identificada como Rede Miquéias, criada em 2016 em evento na Igreja Batista da Redenção em Belo Horizonte (BH) e contou com a presença de representantes da Tearfund, Aliança Cristã Evangélica Brasileira, Rede Fale, Ultimato, Renas, dentre outros.

12 O Corajosamente Éticos designa a entidade criada na África do Sul pelo empresário Grahan Power, em 2010. Com atuação em vários países, no Brasil desde 2015, promove campanhas em favor da ética, "um modo de vida honrado" e o "combate à corrupção".

13 O Exército da Salvação é uma organização cristã internacional, fundada em Londres, em 1865, e atua no Brasil desde 1922. Mantém atendimento a crianças em situação de risco, projetos educacionais e lares para idosos em diferentes estados.

14 Fundada em 1846 na Inglaterra, a Aliança Evangélica Mundial reúne uma rede de organizações e igrejas evangélicas com atuação em centenas de países. No Brasil, conta com a parceria da Aliança Cristã Evangélica Brasileira (ACEB), criada em 2010 na Catedral Metodista de São Paulo, a partir da reunião de denominações evangélicas históricas como: Luteranismo, Anglicanismo, Metodismo, Igrejas Congregacionais, Igrejas Batistas, dentre outras.

15 Fonte: https://www.worldea.org/news/4102/exposed-2013-historic-launch-of-global-christian-response-to-corruption-1. Acesso em: 30/01/2019.

$16 \mathrm{O}$ fundador e presidente do conselho diretivo da associação é o advogado Uziel Santana, membro da Igreja Batista Betel de Aracaju (SE) e professor de Direito da Universidade Presbiteriana Mackenzie e da Universidade Federal de Sergipe (UFS). Em 2019, a entidade reunia 600 associados e mantinha coordenações estaduais em 23 unidades federativas. Segundo Vital da Cunha, além da identidade religiosa, os atores reunidos na associação "conformam um grupo de poder" (2020). 
campanha, com uma proposta sobre os males que provoca a corrupção e propostas de ação, dizia: "Corrupção Mata! Exponha-a! Denuncie! Ponha um foco de luz na Corrupção.” A campanha promoveu uma vigília de oração e de coleta de assinaturas em apoio ao documento (o "Chamado Global") que seria entregue aos líderes do G20 solicitando maior transparência nas transações financeiras. A divulgação da Campanha Exposed contou com o apoio, dentre outras entidades evangélicas, da Rede Fale, Aliança Cristã Evangélica Brasileira, Editora Ultimato, ${ }^{17}$ Ame a Verdade: Evangélicos contra a Corrupção e Tearfund (The Evangelical Alliance Reflief Fund). ${ }^{18}$

Criada após a Segunda Guerra Mundial, a Tearfund atua em mais de 50 países. Há 30 anos no Brasil, apoia projetos especialmente nas regiões Norte e Nordeste. Um dos produtos do envolvimento da entidade com o tema da corrupção foi a publicação do livro Por que defender e promover direitos na área de governança e corrupção, de 2012. O livro concebe a corrupção como um problema econômico e fonte da desigualdade e pobreza. Com base em exemplos de países que usaram ferramentas anticorrupção, ${ }^{19}$ o livro defende que os governos trabalhem com organizações e legislações internacionais de combate à corrupção como a Convenção das Nações Unidas Contra a Corrupção e a Convenção Contra o Suborno, da Organização para a Cooperação e Desenvolvimento Econômico (OCDE). ${ }^{20}$ Parlamentares são objeto de um capítulo e estimulados a se engajarem no combate à corrupção através da participação na Organização Global de Parlamentares Contra a Corrupção.

A Campanha Nacional de Combate à Corrupção, também referida na foto, foi lançada em março de 2015 pela Ordem dos Advogados do Brasil (OAB). Trata-se de mais uma campanha que surge na esteira da Operação Lava Jato e concebe a "corrupção eleitoral" como a fonte da corrupção política no país. O objetivo da campanha foi divulgar o Plano de Combate à Corrupção, também criado pela $\mathrm{OAB}$, que defendia, dentre outros aspectos, a regulamentação da Lei Anticorrupção (Lei no 12.846/2013) e o fim do financiamento empresarial nas eleições. Duas semanas após o lançamento da Campanha, o Plano de Combate à Corrupção foi apresentado a lideranças políticas da Câmara

17 A Editora Ultimato foi criada em 1968 por um pastor presbiteriano e possui uma publicação bimestral. É uma das parceiras da área de comunicação da Aliança Cristã Evangélica Brasileira na produção de cartilhas e matérias para o site.

18 A Rede Fale é uma entidade com sede em São Paulo e foi criada em 2001 sendo resultado de uma conferência missionária entre membros da Aliança Bíblica Universitária (ABU) do Brasil e o grupo Speak, de origem da ABU inglesa. Suas ações são centradas na produção de boletins e campanhas acerca de temas como saneamento, crianças e adolescentes em situação de risco, pobreza e desigualdade, dentre outros.

19 São exemplos, o aperfeiçoamento dos instrumentos para denúncias de suborno na Índia, a inclusão da população na discussão de orçamentos locais no Nepal, o monitoramento pela população dos gastos com educação no Zâmbia e a supervisão parlamentar contra a corrupção no Reino Unido.

20 A Convenção das Nações Unidas contra a Corrupção, adotada pela Assembleia Geral da ONU em 2003, foi promulgada no Brasil através do Decreto $n^{\circ}$ 5.687, de 31 de janeiro de 2006. A Convenção sobre o Combate a Corrupção de Funcionários Públicos Estrangeiros em Transações Comerciais Internacionais, adotada pelo Conselho da Organização para a Cooperação e Desenvolvimento Econômicos em maio de 1997, foi promulgada no Brasil através do Decreto n⿳⺈ 3.678, de 30 de novembro de 2000. O Decreto $n^{\circ} 4.410$, de 7 de outubro de 2002, por sua vez, promulga a Convenção Interamericana contra a Corrupção, da Organização dos Estados Americanos (OEA), adotada em março de 1996. 
dos Deputados, do Senado Federal e à presidente Dilma Rousseff. Se há informações disponíveis sobre a participação da $\mathrm{OAB}$ em campanhas de combate à corrupção promovidas pela Conferência Nacional dos Bispos do Brasil (CNBB), não as localizamos, no entanto, em relação às iniciativas de igrejas evangélicas. $\mathrm{O}$ envolvimento das duas entidades nestas campanhas e a participação da CNBB no Encontro sobre Governança e Transparência Pública promovido por entidades evangélicas são as únicas informações que dispomos para entender a inclusão do logotipo da Campanha na foto.

O coletivo Ame a Verdade: Evangélicos contra a Corrupção, criado em Brasília em abril de 2013, é produto de discussões sobre o envolvimento de igrejas e entidades evangélicas no combate à corrupção. Em 2012, promovido pela Tearfund, teve lugar na cidade de São Paulo o Workshop sobre Governança e Corrupção. No evento, os debates avaliaram a "importância de mobilizar a igreja brasileira contra a corrupção" e a necessidade de discutir o assunto com "outras organizações cristãs e líderes eclesiásticos". Essas questões são retomadas, no ano seguinte, no Encontro sobre Governança e Transparência Pública, realizado em Brasília. Tendo como promotores organizações como a Tearfund, Rede Fale, Rede Evangélica Nacional de Ação Social (Renas), Aliança Cristã Evangélica Brasileira, Aliança de Negras e Negros Evangélicos do Brasil (Anneb), ${ }^{21}$ entre outras, o encontro reuniu cerca de 50 lideranças evangélicas, o Secretário Executivo da Comissão Brasileira de Justiça e $\mathrm{Paz}$ da Conferência Nacional dos Bispos do Brasil (CNBB), a diretora de Combate à Corrupção da Amarribo Brasil e integrantes da administração pública federal. ${ }^{22}$ No material e registros do Encontro identificamos cartazes com frases que associam a corrupção à morte e à necessidade de mobilização para seu combate, como: "ame a verdade", "a corrupção mata". "Denuncia-a. Junte a tua voz ao milhão de luzes apontadas para a corrupção, que nos [sic] afeta a todos, especialmente aos mais pobres", "sabes porque é tão importante acabar com a corrupção?". Outras fotos registram propostas para a incorporação do tema da corrupção pelas "igrejas" e sua mobilização: "transversalizar a temática da corrupção na igreja", "criar um fórum permanente da corrupção + campanha (vídeos, comunicação em redes sociais)", "dar visibilidade aos principais parceiros do projeto (organizações e denominações)", "ter um site do movimento de enfrentamento da corrupção". O coletivo Ame a Verdade: Evangélicos contra a Corrupção surge como desdobramento dessas discussões.

O Ame a Verdade reúne no momento de sua criação 25 "organizações membro", especialmente igrejas e organizações civis evangélicas de denominações históricas (batistas, presbiterianas e metodistas). Estabelece como objetivos principais o desenvolvimento, a partir da "comunidade evangélica", de ações de sensibi-

21 A Rede Evangélica Nacional de Ação Social (Renas), constituída em 2004, reúne organizações e igrejas evangélicas que atuam na área social. A Anneb, criada formalmente em 2006, promove o fortalecimento do movimento negro evangélico articulando líderes e membros das igrejas evangélicas no Brasil.

22 Nos registros do encontro consta a presença de um assessor da Secretaria de Articulação Social da Secretaria Geral Presidência da República, um auditor da Caixa Econômica Federal e membro do Conselho da Transparência Brasil e um auditor do Tribunal de Contas da União e presidente do Instituto de Fiscalização e Controle. 
lização e de mobilização no enfrentamento da corrupção. Para isso, criou um site e uma página no Facebook por meio dos quais divulga artigos, notícias e fotos. Dentre os materiais divulgados no site, encontra-se um vídeo de divulgação da Campanha Exposed no Brasil. O coletivo também lançou duas cartilhas em período eleitoral, uma em 2016, em parceria com a Tearfund sobre as eleições municipais, e outra de 2018, produzida pela Aliança Cristã Evangélica Brasileira, intitulada Decálogo para bons votos, com 10 dicas para o eleitor votar de maneira consciente. A circulação desses materiais aponta para as afinidades e articulações entre as entidades que incorporam o tema do combate à corrupção entre suas preocupações. Em maio de 2016, o Ame a Verdade assina, com outras 129 entidades, o "Manifesto pelo controle, contra a corrupção e pelo fortalecimento da CGU”. ${ }^{23}$ A principal porta-voz do coletivo é Elda Valim, membro da Igreja Presbiteriana Independente de Cuiabá e ex-auditora do Tribunal de Contas da União (TCU). Ela ocupa o cargo de secretária, representa o coletivo em eventos nacionais e internacionais e atua em entidades de combate à corrupção como a Fundação Amarribo, entidade não religiosa que, desde 1999, desenvolve campanhas contra a corrupção. Ao comparar sua atuação no TCU e no Ame a Verdade, a ex-auditora ressalta o sentido religioso que adquiriu seu engajamento: "Agora eu luto contra a corrupção em nome do Deus do impossível, os outros novos aliados são o povo de Deus; a igreja no Brasil". ${ }^{24}$ A articulação de ideias e atuações entre essas distintas entidades evangélicas ligadas ao combate à corrupção é também sugerida pela localização no mesmo bairro em Belo Horizonte das sedes do Ame a Verdade e Tearfund.

A proposta das 10 Medidas Contra a Corrupção conta com o apoio, entre outros, dessa rede de entidades evangélicas nacionais e internacionais mobilizadas em torno do combate à corrupção. Ela foi apresentada pelo Ministério Público Federal (MPF) em cerimônia realizada na Procuradoria Geral da República no dia 20 de março de 2015, em um contexto de popularidade da Operação Lava Jato. Seu idealizador e principal promotor é o coordenador da força-tarefa da Lava Jato, o procurador curitibano Deltan Dallagnol, ${ }^{25}$ membro da Igreja Batista. ${ }^{26}$ Segundo ele, uma primeira versão da proposta foi concebida em 2013 (Dallagnol 2017). A Lava Jato tornou-se,

23 O manifesto é uma iniciativa da "Frente pelo Controle e Contra a Corrupção", uma reunião de entidades da sociedade civil e servidores da Controladoria Geral da União.

24 A notícia completa com a entrevista da ex-auditora pode ser consultada em: http://ameaverdade.org/noticias/ deixe-justica-subir-como-um-rio-justica-como-um-fluxo-que-nunca-falha/. Acesso em: 16/01/2019.

25 Formou-se em Direito na Universidade Federal do Paraná e ingressou no Ministério Público Federal em 2003. Atuou nas investigações do MPF no "caso Banestado" e obteve um mestrado em Direito na Universidade de Harvard antes de assumir a coordenação da força-tarefa. Para outras informações autobiográficas, ver Dallagnol (2017).

26 Os Batistas são definidos pela literatura especializada como protestantes históricos dentro dos diferentes segmentos evangélicos do Brasil. As Igrejas Batistas são dotadas de independência e autonomia e a sua organização compreende a forma congregacional na qual seus membros participam através de assembleias, aprovação de atas e criação de estatutos. Essas assembleias participativas são reproduzidas em nível local, estadual (convenções estaduais), nacional (com Convenção Batista Brasileira) e internacional (Convenção Batista Mundial) (Mafra 2001). 
portanto, uma oportunidade para a promoção das Medidas. $\mathrm{O}$ objetivo, atingido um ano depois, era transformá-las em um projeto de lei de iniciativa popular. Para isso, foram organizados no país inúmeros postos de coleta das assinaturas necessárias para a apresentação do projeto de lei ao Congresso. Os defensores ressaltaram a importância das 10 Medidas para aperfeiçoar o combate à corrupção; seus opositores, o caráter anticonstitucional e o retrocesso punitivista das mesmas. A despeito da controvérsia, a proposta obteve mais de 1,7 milhão de assinaturas e, em março de 2016, tornou-se o Projeto de Lei no 4.850/2016.

Além das entidades evangélicas indicadas anteriormente, o envolvimento de Igrejas Batista e de seus fiéis teve um papel importante na divulgação da proposta do Ministério Público e coleta das assinaturas. Em 2010, os batistas reuniam cerca de 3.723.853 membros, sendo, no campo evangélico, o maior segmento dentre os protestantes históricos. O modelo de organização dos batistas é congregacional, com independência e autonomia das igrejas. Existem diferentes entidades representativas das Igrejas Batista, sendo as principais a Convenção Batista Brasileira (1907), Convenção Batista Pioneira do Sul do Brasil (1910), Convenção Batista Independente (1912) e Convenção Batista Nacional (1967). Parlamentares identificados com a denominação Batista têm integrado a Frente Parlamentar Evangélica no Congresso Nacional.

A Igreja Batista do Bacacheri, da qual Deltan Dallagnol é membro, está localizada no bairro de mesmo nome em Curitiba e foi fundada em 1959. A igreja foi escolhida como um dos primeiros locais para o lançamento de sua campanha em favor das 10 Medidas. Em 29 de abril de 2015, cerca de um mês após a divulgação da proposta na PGR, Deltan Dallagnol profere na Igreja de Bacacheri palestra para pastores batistas de Curitiba. Segundo ele, ao terminar a palestra, o pastor da Igreja, Marcos Ferreira, se dirigiu a ele de modo entusiasmado dizendo: "as 10 Medidas são uma questão de justiça e de amor ao próximo. Isso não pode ser só uma iniciativa do Ministério Público. O protagonismo disso precisa ser da sociedade. (...) Vou investir mais tempo nisso" (Dallagnol 2017:209). Dallagnol atribui ao pastor a ideia de recolher as assinaturas da população para a apresentação da proposta como projeto de lei de iniciativa popular ao Congresso Nacional. Essa foi a primeira de várias palestras realizadas pelo procurador em igrejas evangélicas e entidades civis e profissionais.

A partir da palestra, a Igreja de Bacacheri de fato se engaja na campanha através da divulgação das 10 Medidas e da mobilização de seus membros. Para a Revista da Igreja Batista do Bacacheri (RIBB), edição de 16 de agosto de 2015, por exemplo, o pastor Marcos Ferreira escreve um artigo sobre a corrupção. Propõe que o país vive "uma cultura da corrupção" e que esta é produtora de miséria e desigualdade social. Nesse contexto, convoca os membros da Igreja a, em nome da promoção da compaixão e justiça, orar e coletar assinaturas em favor das medidas. Orientações para participação na campanha são destacadas na última página da revista: 


\section{\#CORRUPÇÃONÃO}

- Corra a retioso como um rio ea jostika como ribeiro perener" Amss 5.24

No mes de maio desse ano, durante as palestras sobre familia e cidadania, e apos as 12 horas de oraço na convocacdo Solene, nossa Igreja escreveu, a partir das opiniðes dos participantes, um manifesto contra a corrupsio e em favor das 10 medidas propostas pelo Ministério Público Federal (wmw.dezmedidas.mpt.mp.br). Nosso desafio agora é, como igreja, levantarmos 20.000 assinaturas que propoe que essas 10 medidas sejam aceitas no Congresso Nacional como projeto de tei de iniciativa popular.

COMO SE ENVOLVER:

- Ore pelo nosso pals e por esse movimento. A meta total é de 1 milhaso e melo de assinaturas coletadas em pelo menos 5 estados da federacao;

- Assine o abaixo-assinado e colete pelo menos 10 assinaturas de seus vizinhos, estabelecimentos comercials, trabalho e escolas;

- Separe a data do dia 29/08 - Sibado pela manha - Estaremos juntos na rua XV de novembro realizando o flash Mob sCorrupcajoWata. A saída para o Flash Mob será na 188 as 8 h da manhs.

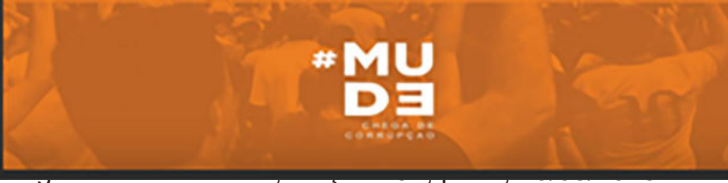

Fonte: https://issuu.com/bacacheri/docs/revista294_web.

Acesso em: 21/02/2019.

Após fazer um resumo do envolvimento da igreja com o tema da corrupção nos últimos meses, o texto convida o leitor a participar das atividades programadas. Dentre elas, destacam-se as orações, uma atividade de rua e o "desafio" de coletar 20 mil assinaturas em favor da proposta do Ministério Público. Alguns meses depois, em novembro, a campanha em favor das 10 Medidas volta a ser assunto de uma nova edição da revista. Na parte superior do texto, com destaque, aparece o logotipo da proposta e, logo abaixo, em caixa menor, as palavras "Novo Desafio". O texto ressalta a importância das 10 Medidas para o combate à corrupção e faz um balanço do número de assinaturas já obtido. Às 20 mil assinaturas reunidas pela Igreja, observa-se que se somam outras 700 mil, "coletadas por diversas iniciativas em todo o Brasil, das quais boa parte é resultado do engajamento de igrejas evangélicas" (Revista da Igreja Batista do Bacacheri, Edição 309:4). O texto termina lançando um novo desafio, a coleta pela Igreja de mais 20 mil assinaturas até março de 2016.

Como na imagem reproduzida anteriormente, no final do texto, consta o logotipo \#MUDE, que conta com o "importante engajamento" da Igreja Bacacheri e se define como um movimento social apartidário que promove ações de combate à corrupção e de fortalecimento da consciência dos cidadãos acerca da corrupção na política pelos seus representantes e nos ambientes públicos. Do ponto de vista de sua organização e composição, o movimento informa que "não temos sede", "é um mo- 
vimento muito orgânico", "são profissionais de diversas áreas" e conta com pessoas que "trabalham voluntariamente". O presidente do Instituto Mude é Fábio A. de Oliveira, diretor comercial na operadora de plano de saúde Evangélico Saúde, formado em Teologia pela Faculdade Batista do Paraná e "conhecido de longa data" do procurador Deltan Dallagnol (Dallagnol, 2017:232). As relações de conhecimento, apoio e doações financeiras do procurador ao Instituto são reconhecidas pelo Ministério Público Federal em nota pública divulgada em resposta aos diálogos atribuídos ao procurador publicados pelo jornal The Intercept Brasil no dia 2/9/2019. Nas trocas de mensagens realizadas por meio do aplicativo Telegram nos anos de 2016 e 2017 aparecem referências a Patrícia Fehrmann (coordenadora de comunicação da Igreja Bacacheri), Marcos P. Ferreira, Fábio A. Oliveira e Hadler Martines (membro da Igreja Bacacheri e revisor do Curso Mude). Os diálogos ocorrem em torno de contatos e reuniões promovidas pelo procurador com empresários visando a obtenção de doações e apoio financeiro para o Instituto Mude e de medidas necessárias para a transformação do Instituto em "pessoa jurídica" de modo que este pudesse passar a receber as doações sem a mediação da Igreja Bacacheri. ${ }^{27}$

Além de divulgar materiais de campanha das 10 Medidas, informações sobre a atuação da Lava Jato, de votações no Congresso Nacional, de decisões do Supremo Tribunal Federal, da votação das 10 Medidas no Congresso e de convocações pelo Facebook, Instagram e WhatsApp, o Instituto Mude promoveu palestras do procurador Deltan Dallagnol em Igrejas Batistas pelo país. Os chamados para as palestras foram postados na página do Mude no Facebook e reproduziam o seguinte modelo de divulgação:

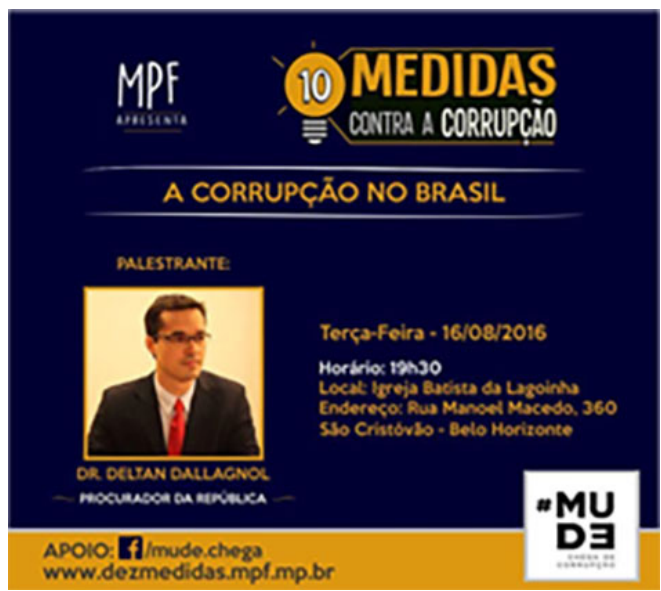

Os convites para as palestras são eventualmente acompanhados de reflexões sobre a corrupção e sugestões de medidas que podem ser adotadas no plano das práticas individuais de combate à corrupção. A divulgação do evento acaba favorecendo

27 Os diálogos contendo as referências ao Instituto Mude estão disponíveis nas matérias do The Intercept Brasil (TIB) do dia 18 de agosto de 2019 e do TIB em parceria com a Agência Brasil no dia 2 de setembro de 2019. 
a transformação da corrupção em uma preocupação da igreja, a difusão de narrativas sobre a corrupção e a promoção das instituições e pessoas que agem em nome de seu combate. Podemos observar como esses elementos operam a partir, por exemplo, de um boletim de fevereiro de 2016, da Primeira Igreja Batista de Campo Grande (RJ), que anuncia a palestra do coordenador da força tarefa. O boletim intitulado "É tempo de combater a corrupção" traz, abaixo do título, o versículo bíblico de Filipenses 2:15. A abertura do texto com a passagem bíblica introduz um sentido religioso ao combate à corrupção ao indicar que alguns dos filhos de Deus estariam no meio de uma geração corrupta, mas que estariam aptos a iluminar o mundo. Em seguida, são elencados seis "passos", resumidos a seguir, para que as pessoas se engajem na luta contra a corrupção: 1) "dizer não a pequenos gestos corruptos" (furar fila, comprar produtos piratas, subornar um guarda); 2) ao presenciar práticas de corrupção passiva ou ativa denunciar ao MPF; 3) fiscalizar, participar de conselhos e audiências públicas que tratem do orçamento; 4) informar-se sobre os gastos públicos na internet; 5) inspirar-se em exemplos de países com baixo índice de corrupção; e 6) divulgar a campanha do Ministério Público Federal. Por último, há o convite para que todos assistam a palestra sobre as 10 Medidas Contra a Corrupção.

A incorporação do tema da corrupção e das 10 Medidas Contra a Corrupção tornou-se corrente nas Igrejas Batistas. A Convenção Batista Brasileira, por exemplo, informa em seu jornal, em uma edição de 2015, na qual mobiliza a imagem da corrupção como um "câncer social", que "o aperfeiçoamento que essas medidas trazem são de grande valia e reduzirão o índice de corrupção no país". Ações em favor das 10 Medidas são divulgadas através de agendas de mobilização e de propostas de atividades. Nesse sentido, as igrejas foram orientadas, num esquema de passo a passo, a promover cultos com mensagens - fundadas em passagens bíblicas - de compaixão e justiça, a desafiar os membros da igreja na coleta de assinaturas, a realizar ações pela cidade com frases que mostrem "como a corrupção paralisa a vida" e a colorir de verde e amarelo as proximidades da procuradoria da república quando da entrega das assinaturas aos procuradores.

Ao longo de 2015 e 2016, a atuação do Movimento Mude foi importante para o recolhimento das 2 milhões de assinaturas entregues no Congresso Nacional no dia 29 de março de 2016. As 10 Medidas foram transformadas no Projeto de Lei (PL) 4.850/2016 e, posteriormente, no PL 3.855/2019, em análise no Congresso Nacional. As ações do Instituto Mude em favor das 10 Medidas, da Lava Jato e do combate à corrupção se estenderam às eleições de 2018.

No dia 20 de maio de 2017, por exemplo, o Movimento Mude participou da Marcha para Jesus em Curitiba. ${ }^{28}$ Durante a Marcha, o Mude divulgou mensagens por meio de cartazes nos quais estavam impressos seu logotipo. Neles constavam frases como: "cada um de vocês deve abandonar a mentira e falar a verdade, Efésios

28 A Marcha é um evento nacional, internacional e interdenominacional e ocorre anualmente no Brasil em diversos estados desde 1993. Ver Sant'Ana (2017). 
4:25"; "quando os ímpios governam o povo geme, Provérbios 29:2"; "não aceite o suborno, porque o suborno cega, Êxodo 23:8", "Lava Jato, eu apoio" e "\#chega de corrupção". No mês seguinte, no dia 29 de junho de 2017, o Movimento Mude promoveu um "adesivaço" em Curitiba chamado de "Ato 29". A manifestação também ocorreu em outras cidades do país e teve como motivação principal relembrar os dois acontecimentos acerca das 10 Medidas: a entrega das assinaturas e a votação no Congresso Nacional.

\section{Combate à corrupção e formação política}

Em março de 2018, o Instituto Mude lançou um curso on-line intitulado Cidadania e Combate à Corrupção. As aulas ocorreram nos meses que antecederam à eleição presidencial e visavam, de modo mais imediato, ter influência sobre o pleito. O curso foi disponibilizado para qualquer interessado e era gratuito. Os temas abordados não se restringiram ao combate à corrupção, mas incluíram discussões sobre cidadania, democracia, Estado, eleições, caixa 2, entre outros. À luz de preceitos religiosos, o curso, portanto, propunha oferecer uma formação política aos alunos. A realização de cursos de formação política para leigos, fiéis e autoridades religiosas não é recente e tem sido frequente entre católicos e evangélicos (Machado 2015; Novaes 2002). O que nos parece relevante no caso do curso do Mude é o fato da corrupção pautar, a partir da perspectiva batista, interpretações sobre instituições e práticas políticas e evidenciar como as narrativas sobre a corrupção postas em circulação por esse segmento evangélico articulam-se com aquelas partilhadas pelo Ministério Público Federal e a organização internacional Transparência Brasil.

O curso foi planejado para ter 30 aulas divididas em 3 módulos. O primeiro módulo propõe refletir sobre "como aproveitar o momento para contribuir com uma mudança cultural no Brasil" e "os instrumentos disponíveis de combate à corrupção". O segundo examina as "medidas de combate à corrupção que precisam ser implementadas" e a eleição de "candidatos comprometidos com o combate à corrupção". O terceiro aborda formas de atuação dos cidadãos no combate à corrupção a partir de "aplicativos, grupos de ação, movimentos sociais, ONGs e instituições públicas". De fato, somente as 20 aulas dos dois primeiros módulos foram oferecidas.

As aulas, semanais, foram conduzidas predominantemente por membros batistas de Curitiba. Com a duração aproximada de 10 minutos, cada videoaula é organizada em torno de dois tipos de roteiro. O primeiro é nomeado "Roteiro para reflexão, diálogo e prática". Nele o leitor é estimulado a refletir sobre questões gerais ("Você considera a corrupção um problema cultural?", "Como você enxerga o famoso "jeitinho brasileiro"') e comportamentos vividos ou observados por ele no dia a dia ("Em que esferas do seu cotidiano você identifica a corrupção?”). Além disso, existem orientações para discussão em grupo na escola, comunidade e perguntas norteadoras, ("Quais são suas percepções acerca da Operação Lava Jato? Expressem suas concor- 
dâncias, divergências e preocupações"). No final do roteiro é proposto um desafio ("Pressionem candidatos para que contemplem suas medidas de combate à corrupção"). O segundo roteiro é chamado "Roteiro para reflexão cristã, diálogo e prática". Neste são reunidas orientações, perguntas e versículos bíblicos que visam fundamentar ações dirigidas para o combate à corrupção. Aqui é importante destacar que os textos bíblicos selecionados atribuem, por meio da mediação das interpretações propostas, um sentido religioso às ações de combate à corrupção. As aulas incluem também trechos de entrevistas, como a do programa Roda Viva com o juiz Sérgio Moro e matérias publicadas na grande imprensa. Além disso, nelas são frequentes as menções à Lava Jato e às 10 Medidas como esforços importantes de combate à corrupção. Sob aparente imparcialidade, pode-se identificar nas perguntas, exemplos, orientações, desafios e no material (entrevistas, reportagens etc.) utilizado nas aulas a difusão de uma compreensão particular da corrupção e das ações empreendidas em nome de seu combate. Na descrição do fenômeno da corrupção e nas soluções apontadas observamos, como argumenta Bourdieu ao refletir sobre as lutas políticas, um projeto de ação sobre o mundo social através da imposição de "representações (mentais, verbais, gráficas ou teatrais) do mundo social” (Bourdieu 1998:117). No caso aqui examinado, os esquemas de percepção difundidos sobre a corrupção envolvem a mobilização de categorias seculares e religiosas. A seguir damos mais atenção ao conteúdo das aulas reunindo-as em três eixos: o uso da cosmologia religiosa, a discussão sobre Estado e política e a divulgação das medidas contra a corrupção defendidas pelo MPF.

Chamam atenção nas aulas os usos de passagens bíblicas, os pedidos de oração e as referências à "cosmovisão bíblica, ao compromisso com o evangelho e ao papel das igrejas evangélicas nas interpretações sobre a corrupção e seu combate. No roteiro da primeira aula, intitulada "Uma janela histórica de oportunidade para nossa geração", lê-se, por exemplo, a seguinte frase: "A situação do discípulo de Cristo, numa situação como a que o Brasil vive, deve ser decisiva. Somos cidadãos do céu, mas também somos cidadãos da Terra e, nas palavras do apóstolo Paulo: "embaixadores de Cristo" (2 Coríntios 5:20) neste mundo". Cabe destacar, inicialmente, que a expressão "janela de oportunidade" era utilizada com regularidade pelo procurador Deltan Dallagnol para defender e solicitar o apoio das pessoas às medidas da operação Lava Jato (Dallanol 2017: 14). No contexto do curso, a ideia da oportunidade de engajamento no combate à corrupção - e na política de uma forma mais ampla, defendida a partir de referências a relatos de personagens das escrituras que atuarem em prol do "bem comum", como Neemias ${ }^{29}$ - é interpretada como um dever cristão. Argumenta-se, nesse sentido, em termos de uma continuidade entre a condição dos cristãos no céu e na terra, um meio de estimular o envolvimento com questões seculares, e do

29 Neemias é um personagem bíblico que, segundo passagens do texto sagrado, participou junto ao povo da reconstrução dos muros de Jerusalém que estavam destruídos e as portas da cidade haviam sido consumidas pelo fogo. Em uma entrevista concedida pelo procurador Deltan Dallagnol à Revista Ultimato, em 2015, a referência a Neemias também é feita sendo caracterizada como "inspiradora" para se pensar no combate à corrupção. 
papel exemplar que os fiéis devem assumir: "vocês são o sal da terra", "vocês são a luz do mundo". Dentre as sugestões de ações que vão sendo apresentadas ao longo das aulas, encontram-se os pedidos aos alunos de que orem pelo país e para que cada um interceda "séria e responsavelmente para que Deus nos conduza na busca por justiça e combate à corrupção".

A história da corrupção é abordada a partir da citação de trechos do livro de Gênesis, publicados originalmente no site da Aliança Cristã Evangélica Brasileira, que descrevem o período entre a criação do homem e a "desobediência da criatura humana": "A terra, porém, estava corrompida diante de Deus, e cheia de violência. Viu Deus a terra, e eis que estava corrompida; porque toda a carne havia corrompido o seu caminho sobre a terra" (Gn. 6.11-12). Nesse contexto, a corrupção é concebida como injustiça e uma forma cruel de violência. A associação do combate à corrupção como busca de justiça social parece ser uma visão dominante entre os batistas. Esse, por exemplo, é o argumento central do artigo de Domingues (2015), no qual a autora defende explicitamente a participação dos batistas "no processo mobilizador contra a corrupção".

As aulas não se restringem ao fenômeno da corrupção. Esse é o gancho para a discussão de temas como democracia, Estado, mídia, fake news, eleições, caixa 2 e voto, entre outros. O Estado é foco de atenção de algumas aulas. São disponibilizadas informações sobre a natureza e a atuação dos poderes Executivo, Legislativo e Judiciário, do Ministério Público, Ministério Público Federal, Tribunal de Contas da União e da Polícia Federal. O trecho abaixo integra um dos roteiros de discussão sobre o Estado. Ele foi produzido após as discussões do projeto de lei das 10 medidas na Câmara, destaca a participação das "igrejas" no apoio às 10 Medidas e anuncia a apresentação de novas medidas, o que de fato aconteceu.

De que forma nós, como discípulos comprometidos com o evangelho, podemos lutar conjuntamente ao MP, MPF, PF e TCU na luta contra a corrupção? Você sabia que as igrejas foram fortíssimas aliadas do projeto das 10 Medidas Contra a Corrupção, proposto pelo MPF?" Infelizmente, esse projeto de lei foi desfigurado pela Câmara na madrugada que sucedeu a tragédia da Chapecoense. Mas mais projetos de medidas contra a corrupção estão por vir. Separem um pouco de tempo de oração (pelo menos 15 minutos) e peçam a Deus que abençoe a luta dessas instituições e da população contra a corrupção.

Na passagem anterior, como ocorre com os diferentes temas seculares abordados durante o curso, noções sobre o Estado e a política são difundidas e articuladas a um discurso religioso e de combate à corrupção. $\mathrm{O}$ curso promove, portanto, a circulação de informações, categorias de entendimento e de ação política. Exceto pelo fato de estarem diretamente relacionados ao tema da corrupção, a "politização 
das categorias religiosas" e a "religiogização de categorias políticas" são fenômenos observados desde os anos 1970, respectivamente, no âmbito do meio católico e pentecostal (Novaes 2002, 2017). Nesse sentido, observa-se que o envolvimento de segmentos evangélicos com o tema da corrupção promove uma forma de familiarização e experimentação das práticas políticas.

Com a proximidade do pleito presidencial, a eleição e o voto são temas também examinados. Em relação a eles, predomina a preocupação com a eleição de "candidatos íntegros" e comprometidos com o combate à corrupção. Em uma das aulas são apresentados recursos que permitem identificar candidatos não envolvidos em corrupção como: consulta ao site do Tribunal Superior Eleitoral acerca da situação dos candidatos em cada estado, utilização do aplicativo "detector de ficha de político" - que permite saber, através do reconhecimento facial, se políticos respondem a processos de corrupção - e acesso ao site do Unidos contra a Corrupção para conferir a lista de políticos que manifestam seu apoio às Novas Medidas de Combate à Corrupção. Na véspera do primeiro turno da eleição, a aula é conduzida pelo presidente do Mude. Nela a corrupção é caracterizada como um "vírus que se prolifera no comportamento de quase todos e que infelizmente atinge os variados setores da sociedade". Nesse contexto, a eleição é descrita como "a chance do Brasil" e, falando em nome do Mude, o expositor defende a Lava Jato, as Novas Medidas Contra a Corrupção e sugere que estas sejam utilizadas como "régua e padrão" para o voto.

Nas menções e discussões sobre o voto, chama atenção a sua associação praticamente exclusiva à questão do combate à corrupção. Assim, elas acabam fixando um sentido muito particular ao ato de votar e ao voto. Como mostram estudos antropológicos sobre o voto realizados desde o fim dos anos 1980, seu significado não é evidente, mas o resultado de contextos e processos singulares (Heredia; Palmeira 2005, 2010). Referindo-se especificamente a universos religiosos, Novaes lembra que para muitos fiéis da Iurd, a participação na igreja "representa a primeira experiência de "conversar sobre a política", de valorizar o voto como escolha baseada em programas e interesses" (Novaes 2002: 92). No âmbito da mesma denominação religiosa, Oro informa que o voto adquire um sentido particular, ou seja, o "sentido de um rechaço do mal presente na política e sua substituição pelo bem, ou seja, por pessoas convertidas ao evangelho" (2003: 58). Em suma, cabe ressaltar que a visão sobre o voto proposta pelo curso, ao lhe atribuir o sentido de combate à corrupção, procura, portanto, excluir outros significados que lhe têm sido atribuídos como: ideológico, programático, adesão, clientelista, familiar, entre outros.

Desde a primeira aula são feitas menções e avaliações positivas sobre a Operação Lava Jato e às 10 Medidas Contra a Corrupção. No segundo módulo, no entanto, esses assuntos passam a receber uma maior atenção, assim como as Novas Medidas Contra a Corrupção, novo pacote de medidas produzido pelas organizações não governamentais (ONG) Transparência Internacional Brasil e Unidos Contra a Corrup- 
ção em parceria com a Fundação Getúlio Vargas (FGV-RJ) e a colaboração, entre outros, do Instituto Mude e MPF. A atenção concedida às Novas Medidas durante o curso on-line pode ser entendida como uma indicação das relações de afinidade entre a atuação de igrejas evangélicas, do MPF e narrativas internacionais de combate à corrupção.

Criada em 1993, a Transparência Internacional (TI) atua em mais de 100 países em nome de um movimento global de combate à corrupção. No Brasil, ela desenvolve atividades desde os anos 2000. As Novas Medidas contra a Corrupção são descritas como desdobramento das 10 Medidas e têm como fonte experiências tidas como de sucesso desenvolvidas nos países nos quais a Transparência Internacional exerce suas atividades. Nas aulas, os alunos tomam conhecimento dos "12 blocos" de assuntos que integram as medidas. Com a eleição presidencial em curso, temas como o foro privilegiado para pessoas no exercício do mandato, caixa 2, enriquecimento ilícito e a prescrição de crimes como a corrupção são examinados à luz das soluções apresentadas pelas Novas Medidas. A relação das Novas Medidas com os valores religiosos é explorada a partir de questões como: "do ponto de vista bíblico, como se combate a corrupção? As Novas Medidas estariam contempladas por uma cosmovisão bíblica?"; "você acha possível que esse projeto receba o apoio da igreja no Brasil?" Além do questionamento sobre como a igreja pode ajudar na divulgação do novo pacote, os alunos são estimulados a promoverem as medidas e a utilizarem o site da rede Unidos contra a Corrupção para pressionar candidatos a se posicionarem em relação ao tema da corrupção e às Novas Medidas.

A análise do conteúdo das aulas revela, portanto, como através da interpretação de textos e da mobilização de significados religiosos, o curso contribui para difundir as narrativas da Operação Lava Jato, do Ministério Público Federal e da Transparência Internacional sobre o tema da corrupção. Nesse sentido, é um ponto de vista particular sobre a corrupção que passa a circular entre segmentos evangélicos e contribui para forjar uma compreensão também específica e interessada sobre o tema

Para finalizar, cabe um último registro. Em 15 de setembro de 2018, o Movimento Mude publica em sua conta no aplicativo Instagram um vídeo com a seguinte legenda: "Os líderes das igrejas evangélicas do Brasil também estão @unidoscontraacorrupção. Diferentes igrejas, diferentes usos e costumes, mas algo em comum: a certeza de que o Brasil precisa se livrar do grande mal que é a corrupção!” À postagem seguem manifestações de apoio à luta contra à corrupção e às Novas Medidas de Combate à corrupção, transformadas em livro, por parte de um leque amplo de lideranças religiosas evangélicas de denominações históricas (Batistas, Anglicana, Presbiteriana, Luterana) e pentecostal (Assembleia de Deus). Passada a eleição presidencial, o livro é objeto de uma discreta menção pela imprensa pelo fato de estar sendo carregado pelo então juiz Sérgio Moro num voo de Curitiba ao Rio de Janeiro, ocasião em que este recebe e aceita o convite do presidente eleito para assumir o Ministério da Justiça. 


\section{Conclusões}

A atenção ao modo como a discussão sobre a corrupção é mobilizada nos círculos evangélicos e, especificamente, Batistas como aqui abordado, permite observar concepções, práticas e relações sociais produzidas em torno do tema da corrupção em um contexto particular, neste caso, de natureza religiosa. Nos afastamos, desse modo, da ideia de que a corrupção e seu combate têm significados e produzem efeitos sociais semelhantes a despeito das lógicas próprias que caracterizam os distintos contextos nos quais estão presentes como preocupação. Ao contrário, o que sugerem os resultados aqui apresentados é que a presença do tema da corrupção no universo empírico aqui delimitado mobiliza sentidos e estrutura relações distintas daquelas que podem ser observadas, por exemplo, nos universos político, empresarial, jurídico ou da imprensa. Uma particularidade evidente do caso aqui estudado é o fato de que o vocabulário e as interpretações bíblicas fornecem um sentido e justificativas religiosas para o engajamento contra a corrupção.

Com base nas informações reunidas, localizamos na segunda década de dois mil um momento importante de incremento de iniciativas de segmentos evangélicos relacionadas à discussão e ao desenvolvimento de um ponto de vista sobre o tema da corrupção. Cabe destacar que uma dimensão central desse processo são as conexões internacionais mantidas pelas igrejas. Como evidenciam a Campanha Exposed e a atuação da Tearfund, essas redes de contatos funcionam como canais importantes de circulação de informações, textos, materiais de campanha, propostas de soluções, recursos financeiros e formas de ação coletiva. Consideradas em suas linhas gerais, observamos que as concepções sobre a corrupção e o combate à corrupção em circulação nas redes religiosas aqui examinadas apresentam afinidades com aquelas difundidas por agências multilaterais como Banco Mundial, ONU, OCDE e entidades internacionais, como a Transparência Internacional. Nesse sentido, ressaltamos os laços de cooperação entre a atuação de entidades evangélicas, a Transparência Internacional Brasil e o Ministério Público Federal.

Apesar de as discussões sobre a corrupção nos círculos evangélicos antecederem a Operação Lava Jato, é importante lembrar que elas ganham força impulsionadas pelas investigações da Operação, com a centralidade que o tema da corrupção adquire nos debates públicos a partir de 2014, as disputas políticas em torno do impeachment da presidenta Dilma Rousseff, as eleições em 2018 e, particularmente, como aqui procuramos demonstrar, a mobilização de igrejas evangélicas em favor das 10 Medidas Contra a Corrupção; estimulada especialmente através das ligações do procurador e coordenador da força-tarefa da Lava Jato com a Igreja Batista de Bacacheri.

A demonstração da mobilização de entidades e igrejas evangélicas e da sensibilização de seus fiéis em relação à questão da corrupção, via mobilização de códigos religiosos é, a nosso ver, a contribuição principal deste texto. Assim, identificamos 
a realização de reuniões e eventos, a formação de entidades, a adesão a campanhas nacionais e internacionais de combate à corrupção, a produção e difusão de textos e informações e a presença de discussões sobre a corrupção e seu combate em atividades religiosas de rotina (cultos, palestras, publicações, encontros, manifestações públicas etc.). Essas medidas e ações, entre outras, contribuem, sem dúvida, para que o tema circule e ganhe projeção entre segmentos evangélicos.

O julgamento da corrupção como tema simultaneamente religioso e político está associado, entre outros, a dois modos de relação das igrejas evangélicas com os processos políticos nacionais. Primeiro, a inclusão da corrupção, tema consagrado politicamente, como item da agenda política de segmentos evangélicos. As manifestações em favor do combate à corrupção têm sido utilizadas como uma forma de qualificar positivamente os candidatos evangélicos e como um modo de estabelecer uma posição diferenciada em relação a outros grupos e partidos políticos. Desse modo, segmentos evangélicos investem numa identidade política através da construção de uma posição pública de combate às práticas tidas como de corrupção. Segundo, observa-se que os debates em torno da corrupção nos círculos evangélicos vêm acompanhados da difusão de visões a respeito da política nacional, como a defesa do voto nas eleições, de julgamentos, como as avaliações negativas sobre os políticos e, de categorias presentes na política nacional, como as ideias de nação e transparência. Desse modo, os debates em torno da corrupção promovem uma compreensão específica das discussões públicas nacionais e conectam as visões e valores de segmentos evangélicos como os aqui examinados a problemas concebidos como nacionais.

\section{Referências}

ALMEIDA, Ronaldo de. (2019), "Bolsonaro presidente conservadorismo, evangelismo e a crise brasileira”. Novos Estudos CEBRAP, vol. 38, nำ 1: 185-213.

ALMEIDA, Ronaldo de. (2017), "Os Deuses do Parlamento". Novos Estudos CEBRAP, Especial de junho: $71-79$.

BOURDIEU, Pierre. (1998), "Descrever e prescrever. As condições de possibilidade e os limites da eficácia política”. In: P. Bourdieu. A economia das trocas linguísticas. São Paulo: EDUSP.

BRATSIS, Peter. (2014), "Political corruption under transnational capitalism". Historical Materialism, n⿳⺈ 22.1: 105-128.

BURITY, Joanildo. (2018), "A onda conservadora na política brasileira traz o fundamentalismo ao poder?". In: R. Almeida e R. Toniol (org.). Conservadorismos, fascismos e fundamentalismos. Análises conjunturais. Campinas: Editora da Unicamp: 15-66.

DALLAGNOL, Deltan. (2017), A luta contra a corrupção. A Lava Jato e o futuro de um país marcado pela impunidade. Rio de Janeiro: Primeira Pessoa.

DOMINGUES, Gleyds S. (2015), "A inserção da comunidade batista no processo mobilizador contra a corrupção". Revista Batista Pioneira, vol. 4, no 2: 425-437.

DUARTE, Luiz Fernando D. (2017), "Valores cívicos e morais em jogo na Câmara dos deputados: a votação sobre o pedido de impeachment da presidente da República”. Religião e Sociedade, no 37 (1): 145-166. 
ESCOBAR, Samuel. (2005), "Orígenes del Movimiento de Sociedades Bíblicas y su contexto misionológico”. Revista Lusófona de Ciência das Religiões, nº 7/8: 21-30.

GLYNN, Patrick; KOBRIN, Stephen J.; NAIM, Moisés. (2002), "A globalização da corrupção”. In: K. A. Elliott (org.). A corrupção e a economia global. Brasília: Editora da UNB: 27-57.

GONÇALVES, Rafael B. (2017), "O envolvimento de parlamentares evangélicos em casos de corrupção na Câmara dos Deputados”. Revista Sapiência: Sociedade, Saberes e Práticas Educacionais, vol. 6: 300-332.

HALLER, Dieter; SHORE, Cris. (2005), Corruption: Anthropological Perspectives. London/MI: Pluto Press/Ann Arbor.

HEREDIA, Beatriz e PALMEIRA, Moacir. (2010), Política ambígua. Rio de Janeiro: NUAP/Relume Dumará.

HEREDIA, Beatriz. (2005), "O voto como adesão". In: L. B. Canêdo (org.). O sufrágio universal e a invenção democrática. São Paulo: Estação Liberdade: 453-475.

LACERDA, Fábio. (2017), "Evangelicals, Pentecostals and Political Representation in Brazilian Legislative Elections (1998-2010)”. Revista Brasileira de Ciências Sociais, vol. 32, no 93:1-23.

LUNA, Nara. (2018), "O julgamento no Supremo do aborto de anencéfalo - ADPF 54: uma etnografia da religião no espaço público”. Horizontes Antropológicos, nº 52: 165-197.

MACHADO, Maria das Dores C. (2015), "Religião e Política no Brasil Contemporâneo: uma análise dos pentecostais e carismáticos católicos". Religião e sociedade, vol. 35, no 2: 45-72.

MACHADO, Maria das Dores C.; BURITY, Joanildo. (2014), "A ascensão política dos pentecostais no Brasil na avaliação de líderes religiosos". DADOS - Revista de Ciências Sociais, vol. 57, no 3: 601-631.

MACHADO, Maria das Dores C. (2013), "Discursos pentecostais em torno do aborto e da homossexualidade na sociedade brasileira”. Revista Cultura y Religión, vol. 7, no 2 48-68.

MACHADO, Maria das Dores C. (2012), "Religião, cCultura e Política". Religião e Sociedade, vol. 32, no 2: 29-56.

MAFRA, Clara. (2001), Os evangélicos. Rio de Janeiro: Zahar.

MARIZ, Cecília. (1999), "A teologia da batalha espiritual: uma revisão da bibliografia". BIB, no 47: 33-48.

MARQUETTE, Heather. (2010), "Corruption, religion and moral development". Religions and development. Working Paper, vol. 42:1-30.

MONTERO, Paula; SILVA, Aramis L; SALES, Lilian. (2018), "Fazer religião em público: encenações religiosas e influência pública”. Horizontes Antropológicos, no 52: 131-164.

MUIR, Sarah; GUPTA, Akhil. (2018), "Rethinking the Anthropology of Corruption". Current Anthropology, vol. 59 (suppl. 18): S4-S15.

NOVAES, Regina Reyes. (2017), “Os 'evangélicos' e a política: reflexões necessárias sobre o Brasil de hoje". Teoria e Debate, ed. 158:1-7.

NOVAES, Regina Reyes. (2002), "Crenças religiosas e convicções políticas: fronteiras e passagens". In: Luis C. Fridman (org.). Política e Cultura. Século XXI. Rio de Janeiro, ALERJ/Relume-Dumará: 63-98. ORO, Ari Pedro. (2003), "A política da Igreja Universal e seus reflexos nos campos religioso e político brasileiros". Revista Brasileira de Ciências Sociais, vol. 18, no 53: 53-69.

ORO, Ari Pedro. (2001), "Religião e política nas eleições 2000 em Porto Alegre (RS)". Debates do NER, no 3: 9-70.

PRANDI, Reginaldo; SANTOS, Renan William dos. (2017), "Quem tem medo da bancada evangélica? Posições sobre moralidade e política no eleitorado brasileiro, no Congresso Nacional e na Frente Parlamentar Evangélica”. Tempo Social, vol. 29, nº 2: 187-214.

ROSAS, Nina. (2013), "Religião, mídia e produção fonográfica: o Diante do Trono e as disputas com a Igreja Universal”. Religião e Sociedade, vol. 33, nº 1: 167-193.

SANT'ANA, Raquel. (2017), A nação cujo deus é o senhor: a imaginação de uma coletividade "evangélica" a partir da Marcha para Jesus". Rio de Janeiro: Tese de doutorado em Antropologia Social, Museu Nacional, UFRJ. 
SANT'ANA, Raquel. (2014), "O Som da Marcha: evangélicos e espaço público na Marcha para Jesus”. Religião e Sociedade, vol. 34, no 2: 210-231.

SMITH, Daniel Jordan. (2007), A Culture of Corruption: Everyday Deception and Popular Discontent in Nigeria. Princeton: Princeton University Press.

SOMMER, Udi; BLOOM, Pazit Bem-Nun; ARIKAN, Gizem. (2012), "Does faith limit immorality? The politics of religion and corruption". Journal Democratization, $\mathrm{n} \times 1$ 1: 1-23.

VITAL, Christina. (2020), Governo Bolsonaro e ANAJURE: barganhas religiosas entre judiciário e política. Disponível em: https://medium.com/religi\%C3\%A3o-e-cultura/governo-bolsonaro-e-anajure-barganhas-religiosas-entre-judici\%C3\%A1rio-e-pol\%C3\%ADtica-27542aea8e1f. Acesso: 02/01/2021.

VITAL, Christina; LOPES, Paulo V. L.; LUI, Janayna. (2017), Religião e Política: medos sociais, extremismo religioso e as eleições de 2014. Rio de Janeiro: Fundação Henrique Boll e Instituto de Estudos da Religião.

VITAL, Christina; LOPES, Paulo, V. L. (2013), Religião e Política: uma análise da atuação de parlamentares evangélicos sobre os direitos das mulheres e LGBTs no Brasil. Rio de Janeiro: Fundação Henrique Boll e Instituto de Estudos da Religião.

Recebido em: 02/02/2020

Aprovado em: 27/02/2021

Marcos Otavio Bezerra* (marcosbezrra@id.uff.br)

* Professor titular da Universidade Federal Fluminense, Niterói, RJ, Brasil. Antropólogo (PPGAS/MN/UFRJ), pesquisador do Núcleo de Antropologia da Política e do Conselho Nacional de Desenvolvimento Científico e Tecnológico.

Gabriela da Silva Moura** (gabrielamoura@id.uff.br)

** Mestra em Sociologia, Programa de Pós-Graduação em Sociologia, Universidade Federal Fluminense, Niterói, RJ, Brasil. 


\section{Resumo:}

\section{Entidades evangélicas e o combate à corrupção no Brasil (2012-2018)}

O tema do combate à corrupção está na origem, na última década, de movimentos e organizações religiosas do campo evangélico. A análise da atuação de organizações evangélicas e do engajamento de Igrejas Batista na campanha em favor das 10 Medidas Contra a Corrupção, promovida pelo Ministério Público Federal, demonstra, primeiro, a importância de redes transnacionais na incorporação da corrupção como preocupação simultaneamente religiosa e política, segundo, o modo como a ideia da corrupção produz relações sociais e significados específicos em um dado meio social e, enfim, o lugar da corrupção, percebida a partir de interpretações bíblicas, nas justificativas para a defesa da participação de fiéis e entidades evangélicas em disputas políticas e projetos de transformação social.

Palavras-chave: religião e política; evangélicos; mobilização anticorrupção; 10 medidas contra a corrupção; Brasil.

\section{Abstract:}

\section{Evangelical entities and the fight against corruption in Brazil (2012-2018)}

The issue of combating corruption has been at the origin, in the last decade, of religious movements and organizations in the evangelical field. The analysis of the actions of evangelical organizations and the engagement of Baptist churches in the campaign in favor of the 10 Measures Against Corruption, promoted by the Federal Public Ministry, demonstrates, firstly, the importance of transnational networks in the incorporation as both a religious and political concern, second, the way in which the idea of corruption produces social relations and specific meanings in a given social environment and, finally, the place of corruption, perceived through biblical interpretations, in the justifications for the defense of the participation of the faithful and evangelicals entities in political disputes and social transformation projects.

Keywords: religion and politics; evangelicals; anti-corruption mobilization; 10 measures against corruption; Brazil. 